\title{
RICE VALUE CHAIN ANALYSIS IN A FREE TRADE AGREEMENT CONTEXT: A DEVELOPING REGION OF THE DOMINICAN REPUBLIC STUDY CASE
}

\begin{abstract}
The aim of the work was to analyse the rice value chain in a developing region of the Dominican Republic to avoid the rice producer's displacement due to the Free Trade Agreement. Primary sources of information such as personal surveys were used. Sociodemographical, agricultural and economical variables were obtained. Absolute and relative frequencies and accumulated percentages were calculated. The two-way dependence between the item to be explained, farm yield, and the explanatory variables was calculated by means of a chi-squared $\left(\chi^{2}\right)$ test of significance between the items. Two-step cluster analysis was carried out to appraise the question of farmers displace. The competitiveness of the farms could be improved by i) the adjustment of the fertilization and phytosanitary doses, ii) the addition of value and price to the rice by post-harvest practice and iii) the proper technical assistance of the farmers. It would be needed to diversify the productions and/or to reduce the costs for the lower competitive $36.67 \%$ rice farmers of Barahona region in the Dominican Republic not to be displaced by the CAFTA-DR. Dominican operators cannot wait for the problems of the commercial channel to be solved by the state and so they must be participants in and promoters of change. This report recommends initiatives that would create sector 'observatories' for prices, product quality, supply and demand in each season. These organisations should be accessible by all the agents along the chain.
\end{abstract}

Keywords: cluster, displacement, yield and competitiveness.

\section{THE FREE TRADE AGREEMENT}

On August 5, 2004, the United States signed the Dominican Republic-Central America-United States Free Trade Agreement (CAFTA-DR) with five Central American countries, Costa Rica, El Salvador, Guatemala, Honduras, and Nicaragua and the Dominican Republic. The CAFTA-DR is the first free trade agreement between the United States and a group of smaller developing economies. This agreement is creating new economic opportunities by eliminating tariffs, opening markets, reducing barriers to services, and promoting transparency. It is facilitating trade and investment among the

\footnotetext{
${ }^{1}$ Ana Belén Collazos Bravo, ETSIIAA. Avda. de Madrid nº57. 34004 Palencia. Universidad de Valladolid. España.

${ }^{2}$ Prof. Félix Rafael Rondón Domínguez, Instituto Especializado de Estudios Superiores Loyola. Padre Ángel Arias \#1. San Cristóbal. República Dominicana.

${ }^{3}$ Prof. Beatriz Urbano López de Meneses, Departamento de Ingeniería Agrícola y Forestal. Área de Economía, Sociología y Política Agraria. Universidad de Valladolid. Avda. de Madrid nº57. 34004 Palencia. España, corresponding author: e-mail: beaturb@iaf.uva.es
} 
seven countries and furthering regional integration. The agreement entered into force for the United States and the Dominican Republic on March 1, $2007^{4}$.

Central America and the Dominican Republic represent the third largest U.S. export market in Latin America, behind Mexico and Brazil. U.S. exports to the CAFTA-DR countries were valued at $\$ 19.5$ billion in 2009. Combined total two-way trade in 2009 between the United States and Central America and the Dominican Republic was $\$ 37.9$ billion.

U.S. exports of agricultural products to CAFTA/DR countries totalled $\$ 3.0$ billion in 2009, as a group it would be the 6th largest U.S. Ag export market. Leading categories include: coarse grains (\$580 million), wheat (\$397 million), soybean meal (\$382 million) and rice (\$223 million). U.S. imports of agricultural products from CAFTA/DR countries totalled $\$ 3.6$ billion in 2009. Leading categories include: bananas and plantains ( $\$ 831$ million), coffee (unroasted) (\$762 million) other fresh fruit ( $\$ 630$ million), raw beet and cane sugar ( $\$ 231$ million), processed fruit and vegetables ( $\$ 183$ million), and fresh vegetables (\$180 million) $)^{5}$.

Nevertheless the free trade agreement could threat the small local grain producers survival. A free trade agreement could increase the number of farmers displaced by grain and agricultural dumping from the U.S. ${ }^{6}$. The United States is dumping five primary farm commodities on international markets, in violation of World Trade Organization (WTO) agriculture rules, hurting farmers the world over. For the local farmers the costs of production of corn, soybeans, cotton, wheat and rice, are higher than the prices at which these commodities are sold on international markets ${ }^{7}$. The lack of profitability of the farms causes the displacement of the farmers ${ }^{8}$.

\section{THE DOMINICAN REPUBLIC VALUE CHAIN}

The farming and food channel is the set of processes and players that handle the product from the producer to the end consumer. The chain can be long, if there are many intermediaries dealing with the product, or short, if there are only a few. One extreme case is a direct channel, when the product reaches the consumer directly from the producer and all its value goes back to the source, where it can contribute to the development of the area of production. A long chain is usually made up of distributors, wholesalers at the products' source and destination, retailers and the end consumer. A short channel, on the other hand, tends to involve just the producer, the distributor and the consumer. Which channel is used depends on the type of product, how developed the channel is, experience in

\footnotetext{
${ }^{4}$ Office of the United States Representative. Dominican Republic - Central America - United States Free Trade Agreement. Executive Office of the President. Office of the United States Representative. Washington DC. 2013

5 ibidem

${ }^{6}$ Wise T.A. Agricultural Dumping Under NAFTA: Estimating the Costs of U.S. Agricultural Policies to Mexican Producers. Global Development and Enviroment Institute Working Paper No. 09-08 Medford, MA, Global Development and Environment Institute. 2010.

${ }^{7}$ Ritchie, M., S. Murphy and M.B. Lake. US Dumping on World Agricultural Markets: Can Trade Rules Help Farmers?. Institute for Agriculture and Trade Policy (IATP). Minnesota. 2003

${ }^{8}$ Webb, P., J. Coates, E.A. Frongillo, B.L. Rogers, A. Swindale and P. Bilinsky. Measuring Household Food Insecurity: Why it's so important and yet so difficult to do. Journal of Nutrition 136: 1404S-8S. 2006
} 
commercialisation, and the relationships between the producers and the rest of the commercial channel ${ }^{9}$. Value chain analysis looks at the way in which the players along the chain deal with the goods passing through their hands to increase or add to their value at each stage. This involves all the links in the chain from production to consumption, including commercialisation, the market and distribution ${ }^{10}$.

In this context, value chain analysis is a very useful strategic planning tool for understanding how the markets work in terms of time, space and form. From a methodological point of view, value chain analysis can be qualitative or quantitative ${ }^{11}$. Qualitative analysis is simply a description of the processes and transactions that take place along the chain. Quantitative analysis makes it possible to see how and how much of the final value of a product is generated at each of the distinct stages of the chain. This, in turn, makes it possible to evaluate how that value is shared out among the players taking part in the chain ${ }^{12}$.

Farming yields have been very low - lower than other sectors - since the second half of the nineteen eighties in Dominican Republic. Production has been affected by climatic factors and the capacity of farmers to consume and save has been reduced, which partly explains the low investment levels, poverty and emigration in rural areas ${ }^{13}$. Moving along the commercial chain, there are other factors that contribute to low yields in farming, a) a lack of product preparation at origin ${ }^{14}$; b) a lack of enterprise spirit among producers and others due in part to the lack of sufficient volume needed in order to make progress along the farming and food channel and, in short, gain access to the market ${ }^{15}$.

\footnotetext{
${ }^{9}$ Urbano López de Meneses, B. and V. Temprano. (2005). Distribución y consumo de productos ecológicos en Castilla y León: Modelos de Canales comerciales, localización y hábitos de consumo. In: Revista de Investigación Económica y Social de Castilla y León. Consejo Económico y Social de Castilla y León. Valladolid. 2005. p. 270-388.

10 Acosta, L. Agrocadenas de Valor y Alianzas Productivas: Herramientas de apoyo a la agricultura familiar en el contexto de la globalización. Oficina regional de la FAO para América Latina y el Caribe. Santiago de Chile. 2006; Peña, Y., P.A. Nieto and F. Díaz. Cadenas de valor: un enfoque para las agrocadenas. Equidad y Desarrollo, enero-junio, 009. p: 77-85. Universidad de La Salle. Colombia. 2008

${ }^{11}$ Hansen, H.G.P. and M. Torero. Resumen de la literatura de cadenas de valor agropecuarias en cinco países centroamericanos. Instituto Internacional para la Investigación de Políticas Alimenticias (IFPRI). San José, Costa Rica. 2008. 130 pp.

${ }^{12}$ Peña, Y., P.A. Nieto and F. Díaz. Cadenas de valor: un enfoque para las agrocadenas. Equidad y Desarrollo, enero-junio, 009. p: 77-85. Universidad de La Salle. Colombia. 2008.

${ }^{13}$ Godínez, V. and J. Máttar. La República Dominicana en 2030: Hacia una Nación Cohesionada. CEPAL. Santo Domingo. 2008; ONE, Dominican National Statistics Organisation. Las zonas rurales de la República Dominicana In: Panorama Estadístico 2008. Año 2, № 9. Dominican National Statistics Organisation. Santo Domingo, Dominican Republic. 2008; Urbano López de Meneses, B. Plan de capacitación de los asentados de la reforma agraria: técnicos, parceleros, mujeres e internos de prisiones. Red Universitaria de Investigación sobre Cooperación para el Desarrollo. La Catarata. Madrid. 2011. 96 pp.

${ }^{14}$ Urbano López de Meneses, B., F. González-Andrés and P. Casquero Luelmo. Market research for the Optimization of the consumer response to the recent award of a Protected Geographical Indication to a local product: Beans from "La Bañeza-Leon" Spain. Journal of International Food and Agribusiness Marketing, 20. New York. 2008. p. 7-32.

${ }^{15}$ Collazos Bravo, A.B., Y. Mesa Florián, F. González-Andrés and B. Urbano López de Meneses. Investigación en Sostenibilidad y Seguridad Alimentaria como motor de desarrollo agrario del Sur,
} 
Several previous studies on value chains in the Dominican Republic ${ }^{16}$ have shown that staple products are usually sold loose in bulk. This is true for bananas, aubergines, yuccas and papayas (which are sold this way as they are not export products), melons, a small percentage of the guineo banana (which is not exported), and tomatoes produced for industry. Sacks are used for rice, the guandul (pigeon pea), onions, hot peppers (because it is not exported), corn and a small percentage of industrially grown tobacco. Crates are used for most of the tomatoes produced for industry, peppers, salad tomatoes, cucumbers and guineo bananas. These are 40-pound crates except for organic guinea for exports, where 28-pound crates are used.

The relationships between farmers and their buyers do not generally last long. There are, therefore, no consolidated relationships, and this explains why the farmers are more concerned about obtaining improved production than about becoming established in the market. Crops such as rice, tobacco or tomatoes for industry lead to more prolonged relationships. This is because these crops need some industrialisation and there are major buyers and intermediaries, such as the mills, factories, industries or tobacco companies with which the producers establish relationships that help to guarantee a place for their product to go. In the case of aubergines, guanduls or corn, the relationships between producers and intermediaries are sometimes based on their trust in their usual retailer ${ }^{17}$.

De Francisco ${ }^{18}$ found that the main players in the chain were the farmers, the intermediaries, the food manufacturers and the consumers. Most farmers sold to lorry drivers (retailers), to industry, to large and/or small markets or to professional agents. Almost half of the producers sold to intermediaries. A lack of sales to supermarkets or the large network of grocery stores, (or colmados, see below) in the country was discovered, and farmers rarely sold to the end consumer.

The country's retail markets are supplied by wholesalers and distribute the products to the consumers. They are the last stage of commercialisation. By far the most important type of retail outlet in the Dominican Republic is the colmado. They are multi-purpose businesses selling all types of foodstuffs, drinks, cleaning products and other goods mainly for household use. The term colmado includes different types of establishments in

para la provincia de Barahona en República Dominicana. En: Actas del VI Congreso Universidad y Cooperación para el Desarrollo. Universidad Politécnica de Valencia. Valencia. 2013. p. 30-44; Urbano López de Meneses, B., M. Rico González and F. González-Andrés. The contribution of agrifood fairs to rural development: the Castilla and Leon region in Spain case study. Economics and Rural Development research papers Vol. 3. Lithuanian. 2008

${ }^{16}$ De Francisco Abad, O. Análisis de la cadena comercial de los productos de la Junta de Regantes canal Ulises Francisco Espaillat: Aplicación al sector hortofrutícola orientado al abastecimiento de Áreas turísticas. Proyecto Final de Carrera. Universidad Politécnica de Madrid. Madrid. 2008; Urbano Terrón, P. and B. Urbano López de Meneses (coords.). Production and commercialization Sustainable Programme. Research in International Co-operation Development Universities Network. La Catarata. Madrid. 2012. 126 pp.

${ }^{17}$ Urbano Terrón, P. and B. Urbano López de Meneses (coords.). Production and commercialization Sustainable Programme. Research in International Co-operation Development Universities Network. La Catarata. Madrid. 2012. 126 pp.

${ }^{18}$ De Francisco Abad, O. Análisis de la cadena comercial de los productos de la Junta de Regantes canal Ulises Francisco Espaillat: Aplicación al sector hortofrutícola orientado al abastecimiento de Áreas turísticas. Proyecto Final de Carrera. Universidad Politécnica de Madrid. Madrid. 2008 
terms of size and business volume, and they are even combined with other business such as supermarkets, bars, discotheques, betting shops and a home delivery service.

Supermarket trading and commercial chains are currently undergoing change in the Dominican Republic. The supermarket chains dominate sales to social groups with a medium-high and high level of purchasing power. The country's leading supermarket chains are: Supermercados Pola and Multitiendas La Sirena (both belonging to the same group, Grupo Ramos, S.A.) and Supermercados Nacional. There are also some major foreign hypermarkets such as Carrefour, which has one store, and Price Mart, which has two. There are also chains aimed at customers with lower purchasing power such as Hiper Olé, Supermercados La Cadena and Supermercados Bravo ${ }^{19}$ (De Francisco, 2008).

In addition, a specific type of market where producers sell directly to consumers without intermediaries was created under programmes promoted by institutional bodies such as the Secretary of State for Agriculture (SEA), which is now the Ministry of Agriculture, the National Institute for Price Stability (INESPRE), and the Inter-American Institute for Cooperation in Agriculture (IICA). The aim was to bring consumers closer to producers so that they could obtain fresher produce at lower prices. "Minimercados" or mini-markets were set up in the city of Santo Domingo. The Producers' Market Programme was later created, which has undergone some changes as there was originally more participation by intermediaries or traders than by farm producers. Finally, Farming Markets were created and were reorganised by the PROMER Marketing Programme so that mobile mobile units operated throughout the country, and, at the same time, the PROALTO "Food for Everyone" programme was also set up to operate over the whole country on Saturdays.

\section{THE DEVELOPING REGION AND RICE PRODUCTION}

It has been estimated that there are about 30,000 rice producers in the country. The total area devoted to rice production is 1.5 million tareas (1 tarea is 0.0629 hectare). Average rice production in the area is 4.38 quintales per tarea. It is grown in all regions of the country, although the main producer regions are: the South West (San Juan de la Maguana), North East (San Francisco de Macorís, Nagua and Cotuí), North Central (La Vega) and North West (Valverde, Dajabón and Montecristi). Rice is the most important cereal in the Dominican diet. It is boiled and served in various ways including with meat, frijol-kidney beans (Phaseolus vulgaris), guandul-pigeon pea (Cajanus cajan), seafood, vegetables and as a rice pudding with milk. It is used industrially to make products such as foodstuffs for children, cereals and drinks ${ }^{20}$.

In this sense, the rice is a basic foodstuff of the Dominican diet. They are eaten two, three or even four times a day by the population. The rice production participation in 2010 was the $25.7 \%$ of the agrarian sector, being the $29.6 \%$ in year 2002 (Table 1). In 2002 the rice was the $0.7 \%$ of the Gross Domestic Product (GDP) in Dominican Republic. This sector became the $0.6 \%$ of the GDP in 2003. Since 2004, when the CAFTA-DR was signed, went down into $0.5 \%$ of the total ${ }^{21}$.

\footnotetext{
${ }^{19}$ ibidem

20 ibidem

${ }^{21}$ Ministry of Agriculture in Dominican Republic. Agriculture Sector Statistics in Dominican Republic (2002-2011). Vice-ministry of Sectorial Planification. Santo Domingo. Dominican Republic. 2011
} 
The Barahona region is located in the southwest part of the Dominican Republic. According the Census, 2008, Barahona has 201,453 inhabitants, 122.1 inhabitants per square kilometre. The $63.3 \%$ of the families are poor and the $21 \%$ of them indigents ${ }^{22}$. The $25 \%$ of the land province is dedicated to agriculture and the agricultural sector is doubled than the rest of the country $(5.21 \%)^{23}$.

Table 1. Evolution of the rice sector in Dominican Republic, value $\left(10^{3} \mathrm{RD} \$\right)$ and percentage of participation in constant prices 1991

\begin{tabular}{|c|c|c|}
\hline Year & Value $\left(10^{3} \mathrm{RD} \$\right)$ & \% Sector participation \\
\hline 2002 & $3,087,521$ & 29.6 \\
\hline 2003 & $2,571,965$ & 25.2 \\
\hline 2004 & $2,436,454$ & 25.6 \\
\hline 2005 & $2,725,131$ & 24.1 \\
\hline 2006 & $3,016,178$ & 24.2 \\
\hline 2007 & $3,164,764$ & 24.9 \\
\hline 2008 & $3,289,523$ & 28.6 \\
\hline 2009 & $3,584,216$ & 25.6 \\
\hline 2010 & $3,873,941$ & 25.7 \\
\hline
\end{tabular}

The aim of the work was to characterize the rice producers at the poor region of Barahona in Dominican Republic to analyse the impact of the CAFTA-RD that could displace the farmers causing their migration and threaten the rural development of the region.

\section{OBJECTIVES}

The general objective of this study was to analyse the rice value chain in a developing region of Dominican Republic to avoid the rice producer's displacement due to the Free Trade Agreement. Specific objectives were:

i) to select a sample of producers and distributors of rice;

ii) to gather field data;

iii) to characterise the rice farmers in Barahona region;

iv) to cluster the less competitive rice farms;

v) to analyse the relationship between those surveyed and the value chain;

vi) to characterise the problems faced by the farming and food chain for rice;

vii) to identify the ways in which value chains contribute to avoid the displacement of the rice producers.

\footnotetext{
${ }^{22}$ ONE, Statistics National Office. Socio-demographic Profile of the Barahona province. Statistics National Office of the Dominican Republic. Santo Domingo. Dominican Republic. 2008, 16p.

${ }^{23}$ ONE, Statistics National Office. VIII National Census of Housing and Population. Statistics National Office of the Dominican Republic. Santo Domingo. Dominican Republic. 2002.
} 


\section{RESEARCH METHODS}

Primary sources of information such as personal surveys were carried out. Sociodemographical, agricultural and economical variables were obtained. A sample of 30 farms in Barahona province in southern Dominican Republic was visited. Categorical and quantitative data were obtained. SPSS 19.0 software package was used for statistical analyses. Absolute and relative frequencies and accumulated percentages were obtained. The two-way dependence between the item to be explained, yield, and the explanatory variables was calculated by means of a chi-squared $\left(\chi^{2}\right)$ test of significance between the items. To accept or reject the null hypothesis $H_{0}$, which implies no relation between the variables, the value of the $\chi^{2}$ statistic and the respective $p$-values were considered and dependence was determined in the light of the frequencies expected and obtained and the corresponding residues. Yield and profitability, considered as the main factors to displaced the farmers ${ }^{24}$, were included in a cluster. Two-step cluster analysis was carried out to appraise the question of farmers displace.

Then a sample of distributors of rice in the Dominican Republic was selected for analysis. A linear methodology was used to study the rice value chain. Firstly, the main players involved in the farming and food chain were identified using a qualitative analysis. Once these had been established, a quantitative analysis determined the problems faced by each one in their relationship with the product' final value.

Categorical and nominal answers were obtained, along with opinion data, which was the reason for choosing the "personal interview" data collection method. The interviews were carried out in July and August 2012 in important production areas of various sizes in the country. Interviewers were used to undertake the interviews and guide respondents through them. The SPSS 19.0 computer program was used to process the data from the questionnaires. Absolute and relative frequencies were obtained for the contingency tables that established the relationships between the socio-demographic, enterprise structure and value chain variables.

To define the recommendations a multi-disciplinary panel of experts was created, made up of Spanish and Dominican technicians who shared the results from the intervention and drew up proposals for lines of action.

\section{RESULTS AND DISCUSSION}

\subsection{Rice producer's characterisation}

The socio-economical variables showed that sampled farmers were men, aged between 31 and 82 years old (47.6\% are 30-45). They have $2-4$ children $(70 \%)$ and have studied Secondary or University level $(60 \%)$. Most of them, $56.7 \%$, cultivated small farms, from 5 to 200 ta $(1 \mathrm{ta}=0.026 \mathrm{ha})$. They are legally owners of the land $(33.3 \%)$ or/and rented $(30 \%)$. The farms are far away $(>5 \mathrm{~km})$ of the decision centers $(63.3 \%)$ (Table 2$)$.

They declared to have private or public technical assistance $(76.7 \%)$. The public assistance came by the Agriculture Ministry, the Reform Institution (IAD) or the Dominican Agrarian and Forestry Research Institution (IDIAF). The private assistance came by suppliers $(30 \%)$, own technicians $(13.3 \%)$ or associations $(6.7 \%)$. Most of them

\footnotetext{
${ }^{24}$ Quiñones Díaz, XE. Mapuche's rural households economy: from the land matter to the profit resources diversification. Spanish Journal of Agrarian and Fishing Studies, 231, 2012. p. 138-173
} 
$(73.3 \%)$ were integrated in associations $(60 \%)$ or cooperatives (13.3\%). Many of them (63.4\%) have access to a credit to buy inputs to cultivate the rice.

The agricultural management revealed that there were no additional workers in the sampled farms $(53.3 \%)$. They used traction for leveling $(63.3 \%)$ and dry traction for tillage (43.3\%). The seeds used were certificated and/or own farm (76.7\%) of Prosequisa 4 variety $(53.3 \%)$ which was direct sowed $(93.3 \%)$. To fertilize they used 15-15-15, sulphate or urea $(56.7 \%$ ) calculated by traditional application criteria $(76.7 \%)$. The $86.7 \%$ of the farmers did not consider analyses to calculate the fertilization dose. The $66.6 \%$ of the farms uses the traditional phytosanitary treatments and chemical applications for weeds control (66.7\%). Traction was used to harvest (96.7\%) and they didn't dried (80\%), dessicated $(93.3 \%)$ or classified $(83.3 \%)$ the grain. Only the $20 \%$ of the farms package the rice grain (Table 3$)$.

Table 2. Distribution of frequencies of the categorical socio-demographic variables for the sample of rice farmers in Barahona province, percentage (\%)

\begin{tabular}{|l|l|r|l|l|r|}
\hline Variables & Value & $\%$ & Variable & Value & $\%$ \\
\hline Age & 30 to 45 years & 30.0 & Organization & No organization & 26.7 \\
\hline & 46 to 60 years & 46.7 & & Co-operative & 13.3 \\
\hline & 61 to 75 years & 20.0 & & Associations & 60,0 \\
\hline & More than 75 & 3.3 & Farm owning & Legal & 33.3 \\
\hline Number children & 0 & 6.7 & & Occupation & 3.3 \\
\hline & 1 & 10.0 & & Rented & 13.3 \\
\hline & 2 & 26.7 & & IAD & 3.3 \\
\hline & 3 & 23.3 & & Others & 30.0 \\
\hline & 4 & 20.0 & & Legal and rented & 16.7 \\
\hline & 5 & 6.7 & Distance & Less 1 km & 33.3 \\
\hline & 7 & 3.3 & & $1-5$ km & 3.3 \\
\hline & 10 & 3.3 & & More 5 km & 63.3 \\
\hline Size farm & $1-50$ ta & 16.7 & Credit & Public & 36.7 \\
\hline & $51-200$ ta & 40.0 & & Private & 26.7 \\
\hline & $201-500$ ta & 30.0 & & No credit access & 36.7 \\
\hline & $501-1000$ ta & 13.3 & Education & Other & 6.7 \\
\hline Technical assistance & No assistance & 23.3 & & No formal & 3.3 \\
\hline & Public assistance & 26.7 & & Start primary & 23.3 \\
\hline & Private assistance & 20.0 & & Primary finish & 6.7 \\
\hline & Private and public & 30.0 & & Secondary & 26.7 \\
\hline & & & & University & 33.3 \\
\hline
\end{tabular}

The agricultural management analysis showed the production could be technical and economically improved by the proper calculation of fertilizers and phytosanitaries doses ${ }^{25}$. The postharvest practices like dry, dessicate or grain classification could add value to the

\footnotetext{
${ }^{25}$ Urbano Terrón, P. and B. Urbano López de Meneses (coords.). Production and commercialization Sustainable Programme. Research in International Co-operation Development Universities Network. La Catarata. Madrid. 2012. 126 pp.
} 
product and improve the competitiveness of the farm against the rice imported by the free trade agreement ${ }^{26}$.

The economical items considered were the yield and the costs, as factors which affect the rents of the farmers and could displace them. The low rents could cause low competiveness and displace the farmers. A wide range of production costs in the sampled farms were found, from 111.83 RD\$/ta to 7474.53 RD\$/ta (Table 4). Have been found rice farms sowed their own seeds, with their own workforce, without machinery and fuel costs, without irrigation or other inputs used, subsequently low production costs. The producers revealed higher costs on fertilization (average 1513.03 RD\$/ta) and worforce (average 1317.56 RD\$/ta). The average yield of the farms were 3.85 quintal/ta (Table 4). Moreover a ratio comparing the relative yield per unit cost was calculated and showed the relative high costs of some rice farms. As some farmers confessed to the interviewers to spend in the crop is a matter of social position for them. In this sense, the farms could efficient each coin invest in the production. A proper technical assistance could improve the profitability of the farms.

Table 3. Distribution of frequencies of categorical agricultural management of rice by the farmers asked in Barahona region

\begin{tabular}{|c|c|c|c|c|c|}
\hline Variable & Value & $\%$ & Variable & Value & $\%$ \\
\hline \multirow[t]{8}{*}{ Workers } & 0 & 53.3 & Leveling & Traction & 63.3 \\
\hline & 1 & 10.0 & & Animal drawn & 13.3 \\
\hline & 2 & 16.7 & & Both & 23.3 \\
\hline & 3 & 3.3 & Tillage & Dry animal drawn & 16.7 \\
\hline & 4 & 6.7 & & Dry traction & 43.3 \\
\hline & 6 & 3.3 & & Wet traction & 13.3 \\
\hline & 7 & 3.3 & & Animal drawn & 16.7 \\
\hline & 8 & 3.3 & & Wet and dry & 10.0 \\
\hline \multirow[t]{2}{*}{ Phytosanitary } & Rutine & 66.6 & Fertilizers & $\begin{array}{l}\text { 15-15-15, sulphate and } \\
\text { urea }\end{array}$ & 56.7 \\
\hline & Control & 33.3 & & $15-15-15$ & 10.0 \\
\hline \multirow[t]{6}{*}{ Sowing material } & $\begin{array}{l}\text { Certificated and Own } \\
\text { seeds }\end{array}$ & 23.3 & & $16-16-10$ & 3.3 \\
\hline & Certificated & 26.7 & & Sulphate & 3.3 \\
\hline & Own seeds & 26.7 & & 16-16-10 and sulphate & 6.7 \\
\hline & Other producers & 6.7 & & $\begin{array}{l}\text { 16-16-10, sulphate and } \\
\text { urea }\end{array}$ & 10.0 \\
\hline & Certificated and suppliers & 10.0 & & $15-15-15$ and urea & 10.0 \\
\hline & Own seeds and suppliers & 6.7 & Aplication & Rutine & 76.7 \\
\hline \multirow[t]{3}{*}{ Sowing method } & Direct sowing & 93.3 & & Planned & 23.3 \\
\hline & Mecanical sowing & 3.3 & Weeds control & Manual and chemical & 30.0 \\
\hline & Mecanical trasplantation & 3.3 & & Manual & 3.3 \\
\hline
\end{tabular}

\footnotetext{
${ }^{26}$ Mandemaker, M., M. Bakker and J. Stoorvogel. The Role of Governance in Agricultural Expansion and Intensification: a Global Study of Arable Agriculture. Ecology and Society, 16-3. 2011; Urbano López de Meneses, B. Análisis de la producción agrícola para la sostenibilidad de la agricultura en la zona norte de la frontera dominico-haitiana. Revista Desarrollo Local Sostenible, 7-18. Eumedia. Málaga. 2014. p. 1-15.
} 
18 A. Belén Collazos Bravo, F. R. Rondón Domínguez, B. Urbano López de Meneses

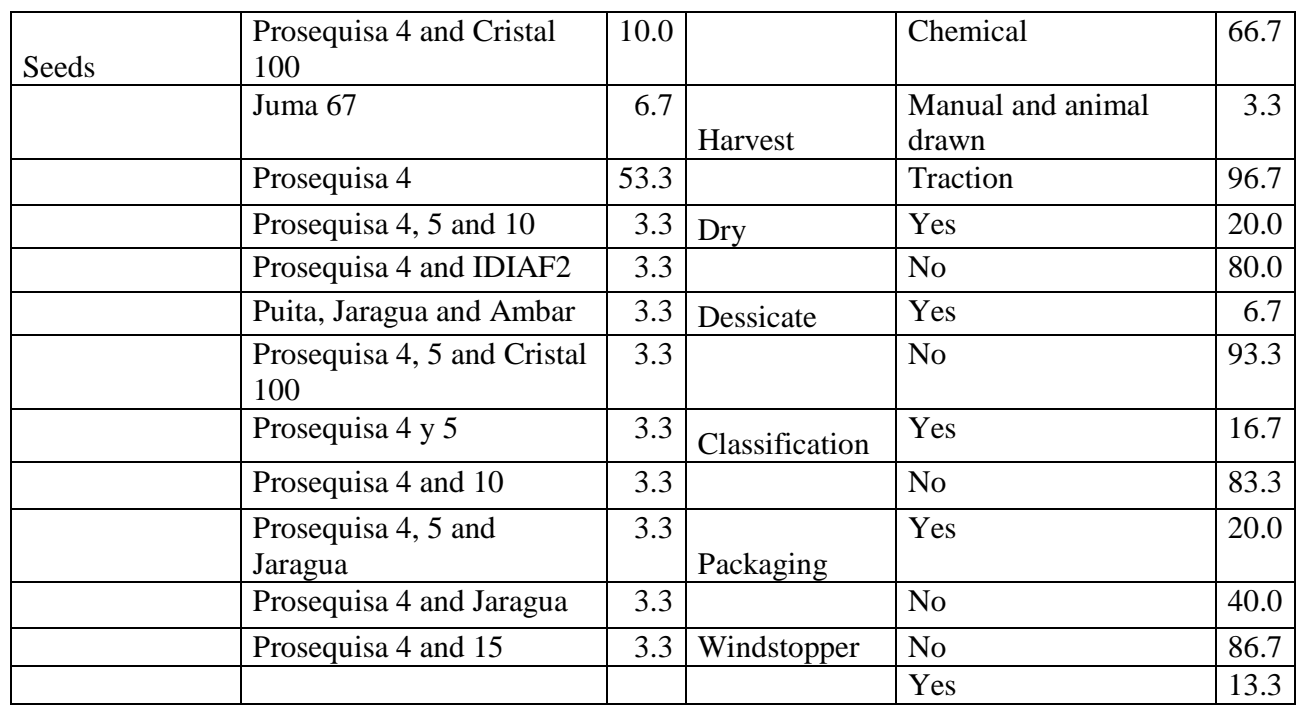

Table 4. Distribution of quantitative variables, maximum, minimum and average value of costs, yield and yield/costs

\begin{tabular}{|l|r|r|r|}
\hline Variable & \multicolumn{1}{l|}{ Min } & \multicolumn{1}{l|}{ Max } & Average \\
\hline Total cost (RD\$/ta) & 111.83 & 7474.53 & 3921.99 \\
\hline Fertilizers costs (RD\$/ta) & 0 & 4000 & 1513.03 \\
\hline Fuel costs (RD\$/ta) & 0 & 1500 & 91.4 \\
\hline Phytosanitary costs (RD\$/ta) & 0 & 2000 & 383.82 \\
\hline Irrigation allowances costs (RD\$/ta) & 0 & 133.33 & 86.13 \\
\hline Workforce costs (RD\$/ta) & 0 & 4245 & 1317.56 \\
\hline Machinery costs (RD\$/ta) & 0 & 2000 & 236.29 \\
\hline Seeds costs (RD\$/ta) & 0 & 600 & 298.44 \\
\hline Package costs (RD\$/ta) & 0 & 909.09 & 139.45 \\
\hline Yield (quintal/ta) & 3 & 7 & 3.85 \\
\hline Yield/cost & 0.000955 & 0.059 & 0.0045 \\
\hline
\end{tabular}

Significant dependences $\left(\chi^{2}<\chi^{2}{ }_{95}\right)$ revealed the relationship between technical assistance, package and yield (Table 5). These results have sense taking into account the importance of the technical support for the profitability of the crops in developing countries $^{27}$. Although most of the farmers revealed to have technical assistance a third of

27 Brandon, K., LJ. Gorenflo, ASL. Rodrigues, and RW. Waller. Reconciling biodiversity conservation, people, protected areas, and agricultural suitability in Mexico. World Development, 33, 2005, p. 1403-1418. 
them came from suppliers that many cases recommend for their own commercial convenience. The technical assistance in this sense could be improved.

The post-harvest practices like package allow add value and competiveness to the rice crop. Also to move forward the value chain improves the crop benefits ${ }^{28}$.

Table 5. Chi-square significance analyses $(\chi 2<\chi 2.95)$ between yield and categorical variables

\begin{tabular}{|l|c|c|c|}
\hline Item & Value & Freedom degree & p-value \\
\hline Technical assistance & 57.551 & 36 & 0.013 \\
\hline Package & 30.000 & 9 & 0.000 \\
\hline
\end{tabular}

The two-step cluster analysis was generated including i) costs and ii) yield, as the main reasons to displace the farmers, and iii) technical assistance and iv) package as the significant variables of profitability. Two clusters of the rice farms were obtained.

Cluster 1 . The $36.67 \%$ of the farms are low competitive. They are farms with high costs, more than $5000 \mathrm{RD} \$ /$ ta and low profitability, less than 0.001 quintal/RD\$. They don't package the rice and don't have technical assistance or doubtable one. They use more than one seed variety. They are medium size farms (60-500 ta) and young farmers. Big farms could reap economies of scope and/or old farmers along the experience curve could reduce the farm costs.

Cluster 2. The $63.33 \%$ of the farms are medium competitive ones. They are farms with competitive costs an enough yield to continue. Nevertheless they have to adapt their farms to the new scenario of the CAFTA-RD agreement signed.

\subsection{Rice Value Chain Analysis}

The operators and distributors in the sample were mostly male (90.3\%), over 40 $(56.1 \%)$ and had over 20 years experience in activities in the Dominican farming and food chain $(64.5 \%)$. The majority of the enterprises were small or medium-sized $(87 \%)$, family run $(83.3 \%)$ and were included in some way in producer, trader or intermediary associations $(58.3 \%)$.

Most of the operators worked with several markets and supplies, with only $8.3 \%$ of the respondents trading in only one product. All other respondents traded in rice, kidney beans or other grains, and fruit and vegetables without distinction.

Most of those surveyed stated that they sold their produce only to distributors $(38.7 \%)$, retailers $(12.9 \%)$ or directly to consumers $(16.1 \%)$. This compares to $25.8 \%$ who sent their produce to consumers, distributors or retailers, or used it for their own consumption, without distinction. These were intermediaries who mostly obtain the produce and send it on to agents in commercials channels leaving very little margin in the producer region. As these are highly rotated, frequently consumed staple products, the distribution channels involve many intermediaries. However, they are also mainly perishable goods and the distance from one operator to the next or to the final user is not usually a long one. As De

\footnotetext{
${ }^{28}$ Martinelli, LA., R. Naylor, P.M. Vitousek and P. Moutinho. Agriculture in Brazil: impacts, costs, and opportunities for a sustainable future. Current Opinion in Environmental Sustainability, 2, 2010. p. 431-438; Rose, DD. Interventions to reduce household food insecurity: a synthesis of current concepts and approaches for Latin America. Journal of Physical Therapy Science, 21, 2008. p. $159-173$.
} 
Francisco ${ }^{29}$ pointed out, there are few products that reach consumers directly and so the product's value does not remain in the area where they are grown.

In $80.6 \%$ of cases the operators stated that they did not receive support for their activities, such as credit for storage, minimum prices or guidance. Despite this, $87.1 \%$ of respondents said they had enough information to operate in the market in terms of price, quality, supply, etc. However, 33.3\% stated that they did not have prior agreements for commercialisation, the other $66.7 \%$ had some kind of commercial forecast for their activity. It can be concluded that products are passed on without any organisation or commercial forecast by a third of the intermediaries and producers. This is often the case for basic, more perishable products. Thus, for the respondents, it was discovered that the perishable the product is (vegetables compared to rice, for example), the greater is the commercial forecasting of the operator with prior agreements being signed $(62.5 \%)$.

All the respondents stated that they carried out quality checks on their products, particularly when selecting seeds and best practice in cultivation. However, only one third stated that they carried out any commercial strategies with regard to product presentation, commercial channels, etc. This confirms what previous studies have found: that those involved are more concerned with production than with consolidation within the market.

$45.2 \%$ of respondents stated that their activity was profitable against $54.8 \%$ who indicated that this was only sometimes the case. $45.2 \%$ of operators said they envisaged good or very good forecasts for their sector, against $22.5 \%$ that said forecasts were uncertain and $32.3 \%$ that said they were bad or very bad. Despite these figures, $91.7 \%$ said they would continue in the sector. Uncertainty about continuing in the sector (in the other $8.3 \%$ ) was due more to the age of the operators than the lack of economic profitability of the process they undertook as it was respondents aged over 50 who said they would not be carrying on.

Likewise, a relationship was seen between continuity and product type. Thus, those working with rice stated uncertainty about continuing in the sector. This response makes sense if rice prices in the country over recent years are considered. In 2007 the Free Trade Treaty came into force in the Dominican Republic, which has led to the increased import of products from abroad. This, in turn, has led many operators to stop dealing with this product as their commercial margins cannot compete with the foreign supplies ${ }^{30}$.

In a similar way, a relationship was also discovered between the age of a respondent and their involvement in an association or corporation of producer-distributors. Thus, producers in the older age range (40-60) had greater involvement in producer, milling or trading associations $(38.7 \%)$. Likewise, a relationship was found between the product handled and association membership. Respondents working with rice and other grains $(58.3 \%)$ had greater integration in such groups as those working with vegetables. This result can be explained by the need for mills and processing industries for these products.

Furthermore, relationships were found between enterprise structure and i) destination for sales, ii) commercial forecasting and iii) degree of association. Thus, medium-sized or institutional enterprises, or those with employees, were not integrated into any producer

\footnotetext{
${ }^{29}$ De Francisco Abad, O. Análisis de la cadena comercial de los productos de la Junta de Regantes canal Ulises Francisco Espaillat: Aplicación al sector hortofrutícola orientado al abastecimiento de Áreas turísticas. Proyecto Final de Carrera. Universidad Politécnica de Madrid. Madrid. 2008.

${ }^{30}$ CEI-RD. Perfil Económico de la República Dominicana. Centro de Exportación e Inversión de la República Dominicana. Santo Domingo. 2012.
} 
associations. These companies usually make cash sales without any commercial forecasting and the products go straight to the consumer $(33.3 \%)$. These results make sense because it is usually the operators who have the most means and infrastructure that can reach the consumer and cut out the intermediaries along the commercial chain by adding value to the products themselves. At the same time, belonging to an organisation allows them to employ more people and carry out greater market research in order to sell for cash at the best price by taking on the technical and economic risks of postponing sales.

According to the respondents, improvement in the value chain would result from improved transparency in the markets, greater clarity in transactions and prices, state aid to establish regulation for transactions, government support to eliminate intermediaries along the value chain and improve greater integration along the chain, state aid to buy supplies and means for farming production, import controls and subsidies for domestic production, improved competitiveness and negotiating power, and improved guidance and training for producers on issues affecting commercialisation.

\section{CONCLUSIONS}

The value chain analysis concluded that it's needed to add value to the local Barahona rice. It's needed to distinguish the local rice of Barahona by a label of origin, flavor, physical or chemical advantages or convenience for local dishes. Local agrifood fairs could inform the consumers about the benefits of the consumption of the local products and their contribution to the life conditions of the local farmers. To improve the competitiveness of the rice farms is essential for the sustainability of the agriculture in the area. The creation of a women rice packaging co-operative could be useful to give value to the product and to diversify the income of the household. The community women cooperative can cook rice milk pudding dessert (with Barahona rice) to be sold in the schools. And more rice manufactured products can be sold by the producers in the multiple tourist business present in the area. The farmers could organize rural tourism routes to show the traditional rice plantations to the visitors of the island's beaches to diversify their activities.

The invitation of technicians or the creation of a scholarship to have some agricultural engineers to advice the farmers in the region can contribute to the sustainability of the farms and to the rural development of the area.

Also could be interesting to diversify the crops and look for more competitive (Chinese veggies, banana, fruit trees, etcetera) or profitable crops for the region. Essays and experimental need to be test according to the demand and the markets to adapt the agricultural region to the new scenario. Moreover the farmers associations could invest to innovate the production technology to be shared by the producers to improve their competitiveness.

Dominican operators cannot wait for the problems of the commercial channel to be solved by the state and so they must be participants in and promoters of change. This report recommends initiatives that would create sector 'observatories' for prices, product quality, supply and demand in each season. These organisations should be accessible by all the agents along the chain. 


\section{REFERENCES}

[1] Acosta, L. Agrocadenas de Valor y Alianzas Productivas: Herramientas de apoyo a la agricultura familiar en el contexto de la globalización. Oficina regional de la FAO para América Latina y el Caribe. Santiago de Chile 2006.

[2] Brandon, K., LJ. Gorenflo, ASL. Rodrigues, and RW. Waller. Reconciling biodiversity conservation, people, protected areas, and agricultural suitability in Mexico. World Development, 33, 2005, p. 1403-1418.

[3] CEI-RD. Perfil Económico de la República Dominicana. Centro de Exportación e Inversión de la República Dominicana. Santo Domingo 2012.

[4] Collazos Bravo, A.B., Y. Mesa Florián, F. González-Andrés and B. Urbano López de Meneses. Investigación en Sostenibilidad y Seguridad Alimentaria como motor de desarrollo agrario del Sur, para la provincia de Barahona en República Dominicana. En: Actas del VI Congreso Universidad y Cooperación para el Desarrollo. Universidad Politécnica de Valencia, Valencia 2013. p. 30-44.

[5] De Francisco Abad, O. Análisis de la cadena comercial de los productos de la Junta de Regantes canal Ulises Francisco Espaillat: Aplicación al sector hortofrutícola orientado al abastecimiento de Áreas turísticas. Proyecto Final de Carrera. Universidad Politécnica de Madrid. Madrid 2008.

[6] Godínez, V. and J. Máttar. La República Dominicana en 2030: Hacia una Nación Cohesionada. CEPAL. Santo Domingo 2008.

[7] Hansen, H.G.P. and M. Torero. Resumen de la literatura de cadenas de valor agropecuarias en cinco países centroamericanos. Instituto Internacional para la Investigación de Políticas Alimenticias (IFPRI). San José, Costa Rica 2008. 130 pp.

[8] Mandemaker, M., M. Bakker and J. Stoorvogel. The Role of Governance in Agricultural Expansion and Intensification: a Global Study of Arable Agriculture. Ecology and Society, 16-3, 2011.

[9] Martinelli, LA., R. Naylor, P.M. Vitousek and P. Moutinho. Agriculture in Brazil: impacts, costs, and opportunities for a sustainable future. Current Opinion in Environmental Sustainability, 2, 2010. p. 431-438.

[10] Ministry of Agriculture in Dominican Republic. Agriculture Sector Statistics in Dominican Republic (2002-2011). Vice-ministry of Sectorial Planification. Santo Domingo. Dominican Republic 2011.

[11] Office of the United States Representative. Dominican Republic - Central America - United States Free Trade Agreement. Executive Office of the President. Office of the United States Representative. Washington DC. 2013

[12] ONE, Statistics National Office. VIII National Census of Housing and Population. Statistics National Office of the Dominican Republic. Santo Domingo. Dominican Republic 2002.

[13] ONE, Dominican National Statistics Organisation. Las zonas rurales de la República Dominicana In: Panorama Estadístico 2008. Año 2, No 9. Dominican National Statistics Organisation. Santo Domingo, Dominican Republic 2008a. 
[14] ONE, Statistics National Office. Socio-demographic Profile of the Barahona province. Statistics National Office of the Dominican Republic. Santo Domingo. Dominican Republic 2008b, 16p.

[15] Peña, Y., P.A. Nieto and F. Díaz. Cadenas de valor: un enfoque para las agrocadenas. Equidad y Desarrollo, enero-junio, 009. p: 77-85. Universidad de La Salle. Colombia 2008.

[16] Quiñones Díaz, XE. Mapuche's rural households economy: from the land matter to the profit resources diversification. Spanish Journal of Agrarian and Fishing Studies, 231, 2012. p. 138-173.

[17] Ritchie, M., S. Murphy and M.B. Lake. US Dumping on World Agricultural Markets: Can Trade Rules Help Farmers?. Institute for Agriculture and Trade Policy (IATP). Minnesota 2003.

[18] Rose, DD. Interventions to reduce household food insecurity: a synthesis of current concepts and approaches for Latin America. Journal of Physical Therapy Science, 21, 2008. p. 159-173.

[19] Urbano López de Meneses, B. and V. Temprano. (2005). Distribución y consumo de productos ecológicos en Castilla y León: Modelos de Canales comerciales, localización y hábitos de consumo. In: Revista de Investigación Económica y Social de Castilla y León. Consejo Económico y Social de Castilla y León. Valladolid 2005. p. 270-388.

[20] Urbano López de Meneses, B., F. González-Andrés and P. Casquero Luelmo. Market research for the Optimization of the consumer response to the recent award of a Protected Geographical Indication to a local product: Beans from "La Bañeza-Leon" Spain. Journal of International Food and Agribusiness Marketing, 20. New York 2008a. p. 7-32.

[21] Urbano López de Meneses, B., M. Rico González and F. González-Andrés. The contribution of agrifood fairs to rural development: the Castilla and Leon region in Spain case study. Economics and Rural Development research papers Vol. 3. Lithuanian 2008b

[22] Urbano López de Meneses, B. Plan de capacitación de los asentados de la reforma agraria: técnicos, parceleros, mujeres e internos de prisiones. Red Universitaria de Investigación sobre Cooperación para el Desarrollo. La Catarata. Madrid 2011.96 pp.

[23] Urbano Terrón, P. and B. Urbano López de Meneses (coords.). Production and commercialization Sustainable Programme. Research in International Co-operation Development Universities Network. La Catarata. Madrid 2012. $126 \mathrm{pp}$.

[24] Urbano López de Meneses, B. Análisis de la producción agrícola para la sostenibilidad de la agricultura en la zona norte de la frontera dominicohaitiana. Revista Desarrollo Local Sostenible, 7-18. Eumedia. Málaga 2014. p. 1-15.

[25] Webb, P., J. Coates, E.A. Frongillo, B.L. Rogers, A. Swindale and P. Bilinsky. Measuring Household Food Insecurity: Why it's so important and yet so difficult to do. Journal of Nutrition 136: 1404S-8S, 2006.

[26] Wise T.A. Agricultural Dumping Under NAFTA: Estimating the Costs of U.S. Agricultural Policies to Mexican Producers. Global Development and 
Enviroment Institute Working Paper No. 09-08 Medford, MA, Global Development and Environment Institute, 2010.

\section{Acknowledges}

This publication has been financially supported by the Spanish Agency of International Cooperation for the Development (AECID) Programme PIE>D 2011.

\section{ANALIZA ŁANCUCHA WARTOŚCI RYŻUW KONTEKŚCIE UMOWY HANDLOWEJNA PRZYKŁADZIE ROZWIJAJĄCEGO SIĘ REGIONY W REPUBLICE DOMINIKAŃSKIEJ - STUDIUM PRZYPADKU}

Celem pracy była analiza łańcucha wartości ryżu w rozwijającym się regionie Dominikany w celu uniknięcia pewnego rodzaju degradacji producentów ryżu ze względu na umowy o wolnym handlu. W artykule wykorzystano ankiety osobowe jako podstawowe źródła informacji. Obliczono społeczno-demograficzne, rolnicze oraz ekonomiczne zmienne, jak również bezwzględne i względne częstości oraz skumulowane odsetki. Aby wyjaśnić wydajność gospodarstw zastosowano relację dwukierunkową, a do obliczeń wykorzystano test chi-kwadrat. Przeprowadzono dwuetapową analizę skupień aby ocenić kwestię degradacji rolników. Konkurencyjność gospodarstw może zostać poprawiona poprzez i) odpowiednie dostosowanie nawożenia i dawki fitosanitarne, ii) wzrost wartości i ceny ryżu poprzez odpowiednie praktyki pożniwne oraz iii) właściwe wsparcie techniczne dla rolników. Niezbędna jest dywersyfikacji produkcji i / lub w celu zmniejszenia konkurencyjnych kosztów dla rolników uprawiających ryż w regionie Barahona na Dominikanie. Plantatorzy nie mogą czekać, aż problem ten zostanie rozwiązany przez państwo, muszą sami stać się organizatorami zmian. W artykule przedstawiono inicjatyw, które pozwolą stworzyć sektor organizacji - „obserwatorów rynku”, którzy dbali by o ceny, jakość produktów, popyt i podaż w każdym sezonie. Organizacje te powinny być dostępne dla wszystkich, którzy są częścią tego łańcucha.

Słowa kluczowe: klaster, wyeliminowanie, wydajność i konkurencyjność.

DOI:10.7862/rz.2014.hss.53

Przesłano do redakcji: czerwiec 2014

Przyjęto do druku: grudzień 2014 